\title{
Value co-creation: the role of actor competence
}

\begin{abstract}
Adopting a Service-Dominant Logic lens, recent research within industrial marketing contexts increasingly recognizes the role of operant resources in value co-creation. Incumbent within operant resources is actor competence. Despite this, an investigation into the role of actor competence in value co-creating processes is scant and the competence literature, in general, has tended to concentrate on specialized knowledge and skills based interpretations that potentially restrict our understanding of the construct. To address this gap, this research adopts a phenomenological approach to explore perceived behavioral attributes of competent actors. Findings confirm two broad behaviorally based conceptualizations of competence: 1) extra-role behavior demonstrated through organizational citizenship behavior, and 2) in-role behavior demonstrated through understanding of work, and engagement behavior. To this end, the contribution of this research is twofold. First and from a theoretical perspective, it offers empirical insights into a relational based framework of competency within industrial marketing contexts. Second, and from a pragmatic perspective, this framework may aid managers in developing a broader understanding of actor competence and how such competencies may be enhanced within the workplace to optimize value co-creation.
\end{abstract}

Keywords: Value Co-creation, Competence, Phenomenology, Relationality Framework

Funding: This research did not receive any specific grant from funding agencies in the public, commercial, or not-for-profit sectors. 


\section{Introduction}

The role of individual actors in value creation processes has long been recognized within an industrial marketing context (e.g., IMP Group, 1982). Latterly, much research within this context has viewed such processes through the emergent lens of Service-Dominant(S-D) logic (e.g., Kowalkowski, 2010; Kohli, 2010). Inherent within the S-D logic is the notion of operant and operand resources. Under the Goods-Dominant (G-D) logic historically associated with industrial marketing contexts, operand resources are considered the primary source of a firm's competitive advantage (Kowalkowski, 2010). However, an increasing number of researchers are recognizing the role of operant resources in creating value within such contexts(e.g., Ueda, Takenaka, Váncza \& Monstori, 2009; Gummerson, 2011). Incumbent within operant resources are the competencies (physical and mental) of actors involved in value creating processes. Such competencies are frequently both dynamic and difficult to transfer and hence potentially a source of sustained competitive advantage in their own right (Lusch and Nambisan, 2015).

Despite this, there is limited conceptual understanding of the competence construct particularly within an industrial marketing context where there is an over-reliance on specialized knowledge and skills based interpretations that potentially restrict our understanding(Sandberg, 2000).Specifically, research into actor competence that manifests in individual behaviors that facilitates value at both the organizational and individual level is identified as requiring further investigation (e.g., Vargo, Maglio, and Akaka, 2008). This research addresses this gap by increasing our understanding of the role of actor competence in value creation processes within an industrial marketing context. To this end, the contribution of this research is twofold. First and from a theoretical perspective, it offers empirical insights into a relational based framework of competency within such contexts. Second, and from a pragmatic perspective, the framework may aid managers in developing a broader understanding of actor competence and how such competencies may be enhanced within the workplace to optimize value co-creation.

The paper is structured as follows. First, competence as a construct is examined and relevant relational characteristics are identified. Next, the methodology consisting of an empirical investigation drawing on phenomenology is outlined. Thereafter and reflecting the themes identified in our analysis, the findings are presented in three key areas: organizational citizenship 
behavior, understanding of work and actor engagement. Finally, our discussion of the findings elaborates on the proposed competence framework before conclusions are drawn and directions for future research are suggested.

\section{Dimensions, levels, and roles of Competence}

The nature of value and its creation has been the focus of much scholarly debate in recent years (e.g., Prahalad \& Ramaswamy, 2004a, 2004b; Vargo \& Lusch, 2004). In conceptualizing value creating processes, Grönroos and Voima (2013) propose the notion of value 'spheres' and specifically, the relative importance of provider spheres and the roles of internal actors within these(e.g., Grönroos, 2008, 2011; Grönroos \& Ravald, 2011). Encompassed within the provider sphere are the firm's operant and operand resources. However, a review of the operant resource literature reveals only a cursory discussion on the role of actor competence (e.g., Vargo \& Lusch, 2006; Madhavaram, Granot \& Badrinarayanan, 2014). In order to fully appreciate the potential impact of actor competence on value co-creation, a more in-depth review of the competence construct is necessary.

\subsection{Dimensions of Competence}

Competence, as a construct, is not only nebulous (e.g., Le Deist \& Winterton, 2005; Weinert, 1999) but subject to differing interpretations dependent upon the underlying epistemological position of scholars (Pate, Martin, \& Robertson, 2003). From an organizational perspective, a review of the extant literature identifies three generic approaches to classifying competence: the actor approach, the work-based approach, and the multi-method approach (Sandberg, 2000). Actor based competence is formed through performance and defined as the ability or capability that an individual possesses (Boyatzis, 2008). The work-based approach emphasises work/job descriptions and/or job analysis. Within a multi-method approach, job, actor, and the organizational environment are taken into consideration (Boyatzis, 2008). However, all these approaches assume that the tasks and situations during the execution of the work are fixed and predictable (e.g., Attewell, 1990; Billett, 2001; Blackler, 1993). In focusing on such rational attributes of actors and/or their job performance, this classification may only provide narrow insights into competence, whilst ignoring the complexities and subtleties that may underlie a broader interpretation of the construct (Sandberg, 2000, 2001). Consequently, a growing number 
of academics are challenging this 'superficial' view and adopting a more phenomenologically based interpretation of the construct (e.g., Sandberg \&Targama, 2007; Nätti, Pekkarinen, Hartikka, \& Holappa, 2014).

The constructivist perspective views competence as the accumulation of an individual's work experiences (Sandberg, 2000) and their understanding of and interaction with a job (e.g., Pate et al., 2003; Katz \& Kahn, 1978). By adopting such a perspective, the conceptual depth of competence may be expanded to include experiential, relational, dynamic, spatial, and temporal dimensions (Sandberg \& Targama, 2007). An experiential dimension recognizes an individual's sense making of their intra-subjective experiences (Sandberg, 2000; Sandberg \& Pinnington, 2009). The relational dimension suggests an individual's competence is socially inter-subjective (Helkkula et al., 2012) and necessitates an understanding of relational structures and their fluidity within specific contexts (Nätti, Pekkarinen, Hartikka, \& Holappa, 2014). Such experiences are dynamic (Pollio, Henley, \& Thompson, 1997) as an actor's sense making may be socially relative to their interactions (FitzPatrick, Varey, Grönroos, \& Davey, 2015; Haas, Snehota, \& Corsaro, 2012). An actor's experience is both temporal and spatial in nature. The temporal dimension could be relative to past, future, or current situational factors (Belk, 1975), while spatial dimensions are dependent on the actor's individual and social contexts and the 'stock of knowledge' of their individual lifeworlds (Schutz, 1967) and the interactions within it.

\subsection{Levels and roles of Competence}

Competence may also be analyzed in terms of levels of self-concept (i.e. personal, relational, and collective)and competencies pertaining to each of these (Brewer \& Gardner, 1996). The relational aspect of self refers to the relationship between the self and another individual. At a group level, the collective self-concept corresponds to the connection of self with a group(Ashmore, Deaux, \& McLaughlin-Volpe, 2004). Within the relationality framework (FitzPatrick et al., 2015), levels of self-concept include 'I', 'Other', and 'We'.The 'I' domain refers to the individual self, the 'Other' domain refers to another person with whom the 'I' is relating, and the 'We' domain refers to the relatedness between ' $\mathrm{I}$ ' and 'other'. These domains indicate that higher relationality is actualized in direct dialogical interactions characterized by collaboration within the 'We' domain. By adopting such a framework, it is possible to identify 
an actors competence in the 'Other' and 'We' domains as well as the 'I' domain traditionally associated with the possession of technical skills.

Individual actors have multiple roles and social identities that vary in terms of their nature and characteristics (Wendt, 1994). The management of these multiple roles is both complex and significant for both the individual and the organization (Rothbard, Phillips, \& Dumas, 2005). Within organizational contexts, individuals fulfill roles with an anticipated performance-related outcome that necessitates particular behaviors and actions(Katz \& Kahn, 1978). To achieve these outcomes, there must be an understanding of work. Such an understanding refers to the actor's knowledge, skills, and other attributes used in accomplishing work-related outcomes rather than merely a list of role specific attributes (Sandberg, 2000). Through mobilizing these knowledge, skills, and attributes, an actor will identify appropriate behaviors and actions to achieve expected organizational outcomes. Such behaviors and actions are also dependent upon an individual's cognition, consciousness, emotions, and values (Dennis, King, Fiore, \& Kim, 2007) and frequently encompass collaborative activity with other actors within a firm. Katz and Kahn (1978) classify roles behavior into two generic categories: in-role, and extra-role behaviors. Inrole behavior relates to the organizational expectations of an individual and frequently forms the basis of ongoing performance assessments (Katz, 1964). In an organizational context, the absence of in-role behavior leads to negative consequences such as limited or no financial rewards, lack of promotion and potential loss of a job. These behaviors are defined in advance and recognized by a formal rewards system. In contrast, extra-role behaviors refer to an individual's behaviors not specified in advance for a job role and consequently have no anticipated reward systems associated with them. However, extra-role behaviors may play a key role in enhancing organizational performance.

To summarize, a review of the literature in relation to actor competence and its role in value cocreation reveals only abstract depictions at a macro-level. Detailed investigations of individuals and their associated competencies relative to the firm's operant and operand resources in value creation processes remains scant (e.g., Ranjan \& Read, 2014). Consequently, further empirical research at a fundamentally lower level of analysis is required if a more comprehensive 
understanding of such processes and specifically, the role of actor competence, is to be achieved (e.g.,Storbacka, Brodie, Böhmann, Maglio, \& Nenonen, 2016; Felin, Foss, \& Ployhart 2015).

\section{Methodology}

The main purpose of this study is to investigate actor competency and its impact on value cocreation. Given the nature of this topic and its complexities, a phenomenological approach was deemed appropriate. Such an approach is suitable when there is a lack of understanding of a phenomenon and exploratory research can offer the potential to improve our understanding of human behaviors (Miles and Huberman, 1994). Specifically, this approach permits an in-depth exploration of actors' interpersonal lived experiences with others and how such interactions contribute to value creation (Patton, 1990; Remenyi et al., 1998). Given the intensive nature of such an approach, it was imperative to choose an appropriate organizational context in which to conduct the study (Story, Raddats, Burton, Zolkiewski and Baines, 2017) and consequently, a large tile manufacturing firm with over 1,800 employees provided the focus for our investigation. This firm was selected for two key reasons. First, the maturity of the market and the relative simplicity of the product provide an opportunity for the identification and investigation of competency related behaviors that may be more difficult within more dynamic market contexts where the products have a higher degree of complexity. Second, the principal researcher had previous working experience at the company and was granted full access for data collection purposes across all levels and functions within the organization. Such experience and tacit knowledge proved invaluable in understanding production and management processes and consequently, the principal researcher was able to concentrate directly on the phenomenon under investigation. Additionally, the principal investigator was perceived as an internal member of the organisation and the researcher's intentions were trusted by participants increasing the richness of data collected.

Data collection was in two parts. Initially, participant observation was employed. The principal investigator spent a total of 12 weeks within relevant departments, familiarizing themselves with the processes of the various departments, its employees, their roles and responsibilities and the day-to-day routines and activities these encompassed. This period involved visiting a number of sites including the head office, two plant offices, and regional sales offices. Field notes were 
taken relating to both specific observations, such as casual conversations and customized routines, as well as more generalized observations such as the culture of each department. Such observations were conducted within the natural environment of the employees (e.g., over lunch, during casual conversations etc.) contributing to an increased contextual understanding of behaviors disjunct of work/job descriptions and job analysis approaches traditionally associated with competence based studies. In adopting such an approach, alternative perspectives to competencies were identified in an unbiased way and within the natural setting of the workplace. This resulted in 60 pages of field notes with the principal researcher achieving an increased indepth knowledge and understanding of the working environment of the firm, its internal practices and insights into potential participant backgrounds. This latterly facilitated data triangulation related to the experiences and interpretations of actors and subsequent interviews with relevant participants(Taylor \& Bogdan, 1984).

The second stage of data collection comprised the principal researcher conducting a total of 57 semi-structured in-depth interviews of approximately 18 to 90 minutes with employees of the firm. A purposeful sampling approach was adopted based on potential participants' roles, time availability, and accessibility. In total, six management executives, 35 middle managers, and 16 operational employees were interviewed (see Table 1 and Appendix 1 for detailed participant roles). Questions focused on participants' definitions of their roles and their experiences and interactions with individuals they perceived as being particularly competent in relation to value propositions. Experiences were not restricted to the focus firm only but their overall career. Participants were encouraged to elaborate through probing and prompting. All interviews were audiotaped and transcribed verbatim. A number of processes were adopted to ensure the validity and reliability of data collected (e.g., Kvale, 1994, 1995; Lather, 1993; Sandberg, 2005). To ensure communicative validity, the principal researcher briefly explained the research theme to the participants. Secondly, the researcher engaged in an on-going dialogue over lunch, casual conversations, and other informal encounters, which helped to understand participant's perspectives with less bias. Thirdly, interviews were open-ended and followed-up with questions to allow participant sharing of as much information as possible about their interpersonal lived experiences. Pragmatic validity was established by observing the participants in their respective departments. Finally, transgressive validity was achieved by searching for contradictions in the 
experiences shared by participants. To ensure reliability as interpretative awareness, all aspects of participants' experiences were deemed equally important during the collection and analysis phases.

Table 1: Sample characteristics of interview participants

\begin{tabular}{|l|c|}
\hline Management Staff Level & Participants \\
\hline Corporate Level Executives & 3 \\
\hline Upper Management & 3 \\
\hline Middle Management & 35 \\
\hline Lower-Level Management & 16 \\
\hline
\end{tabular}

\begin{tabular}{|l|c|c|}
\hline Gender & Participants & Age Range \\
\hline Female & 5 & $24-35$ \\
\hline Male & 52 & $25-58$ \\
\hline
\end{tabular}

\begin{tabular}{|l|c|}
\hline Functional Expertise & Participants \\
\hline General Management & 3 \\
\hline Sales and Marketing & 15 \\
\hline Production & 11 \\
\hline Finance \& Audit & 10 \\
\hline HR & 5 \\
\hline IT & 5 \\
\hline Supply Chain & 4 \\
\hline Quality Assurance & 4 \\
\hline
\end{tabular}

Data were analyzed using thematic content analysis (Patton, 2002). Data presenting relevant concepts were coded and labeled; however, nodes were kept as free nodes that are disconnected from any structure or hierarchy. By embracing an iterative approach, the themes that emerged were organized into behavioral competence categories. The interpretations of the categorizations were cross-checked to ensure if an alternative interpretation was held. This led to more precise formulations of the categories. Analysis continued until a point was reached where further crosschecking did not add to or change existing categories.

\section{Results}

Findings are presented in three key areas reflecting the themes identified during the analysis of the data; organizational citizenship behavior; respondent understanding of work; and finally, engagement behaviors. 


\section{Organizational Citizenship Behavior}

Organizational citizenship behavior (OCB) refers to the perceived overall, unique aspects of an actor's behavior at work which directly or indirectly contributes towards organizational objectives. OCB may be categorized as an extra-role behavioral characteristic insofar as respondents have perceived competence has manifested itself behaviorally to the strategic benefit of the organization. It is through OCB that participants perceive actors are able to create strategic value for the firm, despite these voluntary behaviors not being recognized by a formal reward system. Categorized as direct or indirect, direct OCBs are behaviors that directly impact organizational objectives. When an individual or dyadic behavior is directed towards organizational objectives and exhibited through loyalty, commitment, fairness, dedication, responsivity, persistence, and conscientiousness, the results may manifest in an exceptional performance for the organization. For example, one respondent shared their experience of direct OCB in relation to the General Manager of Company A that he was working with as a contractor (Vendor X). The surface area on which Vendor $\mathrm{X}$ had to install its equipment was prepared by a third party supplier, (Vendor Y). However, an inspection of the surface area prepared by Vendor Y identified significant defects. Vendor X had two options: either attempt to conceal Vendor Y's defects and install their equipment on a defective surface or inform the General Manager of Company A about the problem and its potential consequences. Vendor X opted for the latter and proceeded with its work only after modifications were made to the defective surface. In return, the General Manager of Company A did not put the entire financial burden of modification on Vendor X, but instead, shared the costs 50/50. The results of the implemented solution were highly exceptional. As the participant explains:

AA1: "Because he [the General Manager of Company $\mathrm{A}$ ] was responsible...he is responsible... Actually, this shows his responsibility towards the project...it was his project ultimately. If I remember, the cost of the project was more than 50 or 60 million USD after completion..., so over there in every aspect, he showed responsibility...And it was a successful project and it resulted beyond our expectations."

Extra-role behavioral characteristics which directly impact actors and indirectly impact organizational interests are known as Indirect OCB. Findings suggest an actor's indirect 
behaviors such as mentoring, guidance, fostering individual growth, delegating authority, motivating, and empowering may impact the performance of other actors and influences the way individuals experience work. By way of example, a participant shared how a consultant joined his organization and influenced their working experiences through his personal behavior. The consultant was able to evoke feelings of pride among employees in the organization and elicit commitment to working with him in attempting to achieve organizational objectives.

MJ2: "He used to guide us actually. When a lot of guidance is given to you then you like to work there for that person, for that organization."

Respondent OJ3 (a finance manager) illustrates how her experiences of a senior manager's behavior towards mentoring her in a previous firm currently influence how she currently attempts to mentor her junior colleagues at the tile manufacturing firm. She elaborates on her experiences by providing details of a specific incident when she was delegated an urgent task as her colleague who was originally handling the project was assigned abroad. The project was particularly complex involving minimum capital requirements to satisfy a bank and necessitated a report being provided to the state bank. In order to prepare such reports, there is a duty to go through a detailed conformance compliance process. The respondent had three days to achieve this. The respondent articulated how a senior manager worked with her on the project over the weekend and as a result, she was able to complete it on time with his guidance. The respondent explained how much easier it would have been for the senior manager to have done the report by himself, but instead, opted to mentor the respondent through a learning experience. The participant states:

OJ3: "And in the end, I thought he just wanted me to learn. I mean he knew all the things... everything. So, with him, the deliverance of work was more like I want to make you learn and I want to make you learn in a way that as she succeeds she will do something good on her own. What made him competent was his approach to making people learn. The biggest reason for it was that he used to teach and make you learn." 


\section{Understanding of Work}

Alongside extra-role competence, it is vital for an actor to exhibit an in-depth understanding of their work and how it contributes towards achieving organizational objectives. Such competence is not solely related to an individual's technical expertise but also encompasses an understanding of appropriate approaches to adopt whilst engaging in work related activities. Participants' revealed the importance of proficiency and mental dexterity in their examples of competent individuals in relation to knowledge, conceptual understanding as well as technical expertise. For example, one respondent referred to how the group Chairman's decisions not only affected his company's strategic direction but the way in which such decisions were perceived by the entire group's businesses.

RA4: "The business... the varied businesses which the group has... as varied as banking engineering, tile, and auto manufacturing to a smaller firm which is making laminated goods. The input which the individual has about the businesses is phenomenal."

Another example was shared by the marketing manager of the company when he explained how a business development manager's in-depth understanding of his technical work resulted in an innovative and financially lucrative new product for the firm. In addition to generating new customers, the firm was subsequently faced with the challenge of how to deal with counterfeits of this product that were subsequently introduced into the market. In addressing this challenge, the business development manager, together with other team members came up with ideas to deal with these counterfeits including changes in promotional strategies for raising awareness about counterfeits and adapting the product's packaging. This had a significant and positive impact on the way the product was perceived in the market among customers (dealers, architects, and consumers). Similarly, his understanding of his functional area affected the development of his business unit. When referring to the business development manager, the marketing manager states:

HN5: "Mr. X plays a vital role in tackling those areas... he knows if we tap we will get good business. He knows how to get the business and knows all the ins and outs of that area." 
Data shows that in the participant's interpersonal experience, the competent individual adopted an action-oriented approach in their work. They not only demonstrated expertise in terms of conceptual understanding and the practical application of their work but also in terms of their overall ability to manage a more holistic approach in knowing how to 'get the work done'. Consequently, during the implementation phases, the individual's decisions and problem-solving would encompass a more holistic and organization-wide perspective. Another example of was provided by a respondent who shared an experience they had with the chairman of the group and mentioned how the group chairman would guide the individual and direct him towards the resources of the company required to effectively solve a particular problem. That said, the chairman was adamant about completing tasks on time and would not accept excuses:

RA6: "The last thing you can do with him is... That you make a commitment to him that yes you would do it and then probably after a few days go back to him and give him five excuses and he does not listen to those five excuses."

\section{Actor Engagement}

Actor engagement focuses on participant's engagement experience with competent individuals. Actors would consider not just one-time interactions but an overall engagement experience with the competent individual as valuable. The interpersonal experience included the overall quality of their interactions and the evolving relationship even if it was at short forums. In their direct interactions, the competent individual would actively listen, encourage participation, and provide feedback. For example, one participant shared how, as a vendor, he worked with a company to implement a particular solution. The company's manager had direct interactions with them which evolved into an ongoing positive relationship. The participant focused on how the company's manager would listen to his ideas, maintains clarity in interactions, and treated him as an equal:

AA7: "We were the vendor of XYZ but he never treated us like vendors- he always treated us like a partner." 
In another experience shared by a participant, (ex-Vice Chairman), he explained how his wife would informally contribute to the business through her interactions and relationship building with relevant actors. In doing so, the Vice Chairman was able to introduce a family culture not only to his firm but in its dealings with its customers by inviting their families to the company's events. The VC's wife would accompany him to various corporate events where the customers' wives would also be present. With these multiple interpersonal interactions, a social relationship was formed and the wives would encourage their husbands to do more businesses together.

ARA8: "I brought Amy into the marketing but she had that DNA again to interact with shopkeepers. She's a multi-millionaire and with her DNA she could interact. She could be comfortable with dealers' wives, and they would be comfortable with her... and that's how the whole thing started to gel and started to work."

Another participant shared an example of how the multiple interpersonal relationships of an individual resulted in company level value co-creation. A new managing director (MD) took over the marketing of the firm's offerings. The MD concentrated on relationship building with a number of dealers that were intermediaries between the firm, its customers, and architects. Interactions focused on developing trust, promise fulfillment, and effective negotiation. Based on these relationships, the firm's offerings were perceived as superior to competitors. The participant stated:

AAA9: "We were the best company, we may not have been the best company but because of this relationship... our dealers made us perceived to be the best in terms of quality, in terms of ...everything."

We summarize the behavioral characteristics of competence identified within the data in Table 2 below. 
Table 2: Characteristics of behavioral competence of value co-creation

\begin{tabular}{|c|c|c|}
\hline \multirow{6}{*}{$\begin{array}{l}\text { Organizational } \\
\text { citizenship } \\
\text { behavior }\end{array}$} & Direct OCB & Indirect $\mathrm{OCB}$ \\
\hline & $\begin{array}{l}\text { Loyal and committed to } \\
\text { organization }\end{array}$ & $\begin{array}{l}\text { Delegating role and authority to } \\
\text { others }\end{array}$ \\
\hline & Fair and dedicated & Helps others to learn and grow \\
\hline & Takes responsibility & Spends time to guide/mentor others \\
\hline & Persistent & Motivates and inspire others \\
\hline & Conscientious & Appreciates and empowers others \\
\hline \multirow{4}{*}{$\begin{array}{l}\text { Understanding } \\
\text { of work }\end{array}$} & Professional expertise & Action Oriented Work Approach \\
\hline & Relevant knowledge of business & $\begin{array}{l}\text { Takes a wider and strategic } \\
\text { perspective }\end{array}$ \\
\hline & $\begin{array}{l}\text { Conceptual understanding of } \\
\text { work }\end{array}$ & Timely decision making \\
\hline & Technical Expertise & Effective problem solver \\
\hline \multirow{7}{*}{$\begin{array}{l}\text { Actor } \\
\text { Engagement }\end{array}$} & Relationship & Interaction Quality \\
\hline & Support in day to day tasks & Good listener \\
\hline & Fulfils promises & Encourages participation \\
\hline & Develops and maintains trust & Directly interacts \\
\hline & $\begin{array}{l}\text { Clarity in understanding others } \\
\text { viewpoints }\end{array}$ & Treats others equally \\
\hline & $\begin{array}{l}\text { Ability to communicate } \\
\text { messages effectively }\end{array}$ & Maintains clarity in interaction \\
\hline & Ability to negotiate & Provides feedback \\
\hline
\end{tabular}

\section{Discussion and Conclusions}

In discussing our findings, we adopt and adapt Fitzpatrick et al.'s(2015) relationality framework to identify key behavioral attributes of competence perceived as co-creating individual and organizational level value by participants (see Fig. 2). In-role behaviors comprise the way an individual understands their work and the way they engage with others. Extra-role behavior comprises organizational citizenship behavior (OCB), which includes both indirect OCB, (i.e., behavior directed towards an individual) and direct OCB, (i.e., behavior directed towards an organization). 


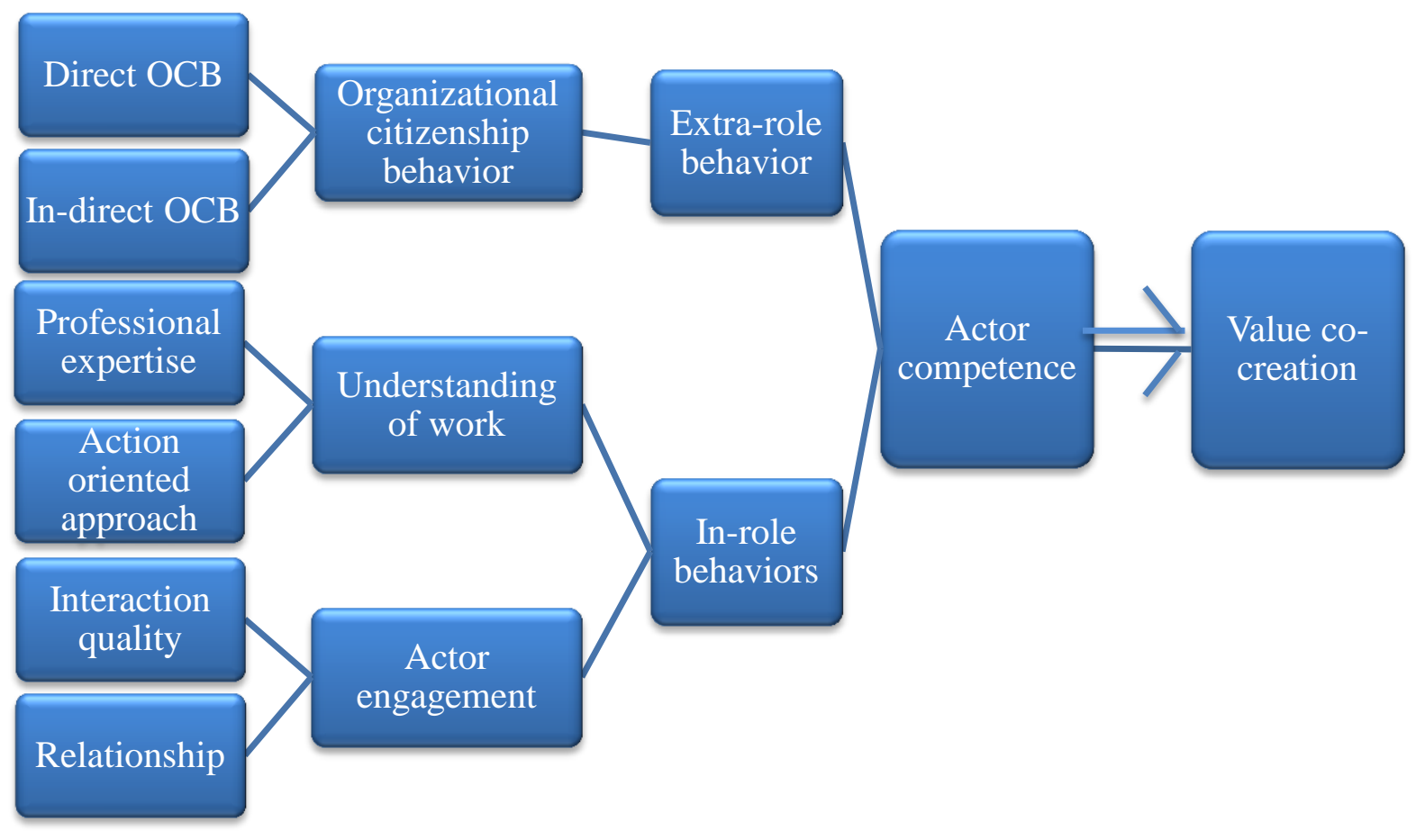

As OCB reflects an individual's discretionary behavior, it is usually not recognized by formal organizational reward systems (Organ, 1988). That said, previous findings have identified that internal actors can advance individual, group, and organizational effectiveness by engaging in such OCBs (e.g., helping others, taking responsibility, being loyal and committed etc. (Katz, 1964)) and are given more positive performance evaluations (e.g., (MacKenzie, Podsakoff, \& Fetter, 1991) and an increased likelihood of personal promotion(Van Scotter, Motowidlo, \& Cross, 2000).

When actors collaborate in a joint dyadic activity with stakeholders, OCBs are the locus of value within value creation processes. Identifying such loci can provide deeper insights of key tenets (FitzPatrick et al., 2015) in addition to being a source of strategic benefit. Our findings provide evidence of strategic benefit to the firm when internal actors exhibit OCBs. At the individual level, the data suggests OCBs facilitate higher affective commitment to the organization. 
Previous research suggests such commitment leads to increased performance outcomes and improved job evaluations, reward allocation decisions, and decreased employee withdrawal (Dekas, Bauer, Welle, Kurkoski, \& Sullivan, 2013). There is also evidence to indicate this may be extrapolated to positive organizational-level outcomes such as increased profitability, productivity, efficiency, cost, and efficiencies (Podsakoff, Whiting, Podsakoff, \& Blume, 2009).

The data also identifies that competence related to an individual's understanding of work is not restricted to professional expertise (e.g., technical expertise) but the person's ability to execute the work through an action-orientated approach (Sandberg, 2000, 2001). The action-oriented work approach reveals that attributes do not have any specific meaning in themselves but meanings are acquired when work is conceived and experienced reflective of previous findings related to competence (Sandberg, 2001). This is demonstrated primarily through taking a wider perspective of the overall business and organizational performance, timely execution of decisions, and effective problem-solving.

Within the context of actor collaboration in joint activities with stakeholders, an actionorientated approach impacts the development and innovation of a firm's offering and thereby, the value outcomes for different stakeholders. At a strategic level, the competence of an individual actor (such as the CEO) to export to an overseas market or to make technological advancements may affect value co-creating processes throughout the firm and beyond. For example, exporting overseas has implications at an organizational level for production, sales, marketing, finance, and customer service departments. Additionally, at a market level, it influences dealers' and customers' perception of the abilities and quality of the firm's offerings in a positive way. Similarly, in providing a platform for value co-creation, the firm introduced new technology to facilitate its customers' interactions. This technology allows customers to co-create their tiles in collaboration with the firm but technological innovation was necessary from the manufacturing plant to enable it. From idea conceptualization to final implementation, the project was highly dependent on internal actor's competence in getting the work completed.

Data also demonstrates that the quality of an actor's episodic interaction experience contributes towards their overall relational quality over time. Reflective of Grönroos and Voima 
(2013)conceptualization, findings demonstrate that value is facilitated through direct interactions, and dependent upon mutual trust, listening, clarity, feedback, encouraging participation, and equality of treatment. As such engagement experiences expand over time. It is not just the quality of interaction but also the overall relationship between perceived competent individuals that improves. This supports the notion that actors engage in direct interactions to expand mutual value together in business engagements through direct dyadic interactions (Grönroos \& Voima, 2013). Such relationships may have consequences for value creation at the network level (Jaakkola \& Hakanen, 2013).

Such insights contribute to our understandings of the emergent phenomenon of engagement and value creation by including internal actors' contribution towards value processes and outcomes. The findings confirm that when market actors interact with competent individuals, their experiences constitutes a central element of the overall engagement and is not just restricted to a one-time interaction. As previously highlighted, direct interactions are engaging, continuous, and dialogical over time (Ballantyne, 2004; FitzPatrick et al., 2015). Interaction and engagement experiences affect not only the individual actors' interpersonal relationships but also extend over time towards a broader network of stakeholders. For example, the relationship of internal actors with a dealer affects the way customers perceive the firm's offering thereby affecting dealers' as well as customers' value outcomes. This is illustrative of how one relationship may affect multiple stakeholders' value outcomes by extending it to other stakeholders' interpretation of the firm’s offering (Zeithaml, Berry, \& Parasuraman, 1993).

\section{Managerial Implications, limitations, and directions for future research}

Managers need to adopt broader, phenomenologically based interpretations of competence by understanding it encompasses the lived work experiences of actors and not purely the application of specialized knowledge and skills. Managers should also benefit from an understanding of the significance of the key behavioral characteristics of actors and their impact on value co-created at both an individual and organizational level. Secondly, organizational frameworks tend to focus on in-role behaviors. The importance of voluntary extra-role behaviors remains understated. Organizational citizenship behavior, a voluntary extra-role behavior, is not formally recognized, but it may have strategic implications for both the organization and their key stakeholders. Such 
insight should help managers set voluntary behavior goals for strategically effective management practices more conducive to value creation. Additionally, promoting extra-role behaviors encourages strong links between the individual and their workplace and enhances their shared sense of work community.

A limitation of this study is its behavioral approach to actor competence. This approach has roots in the behavioral psychology and hence is restricted to explaining only the behavioral aspects of actor competence (Hadjikhani \& LaPlaca, 2013).Future research may undertake different approaches such as affect (e.g., emotions), cognition (e.g., goals) and actor motivation based investigations. Additionally, this study focuses on relational behaviors of competent individuals and thus there is further opportunity to explore personal (individual self-concept), and group (collective self-concept) impact on value co-creation. Finally, the data was primarily based on empirical material from in-depth interviews supplemented by extensive observations. However, video observations when individuals are carrying out their work over an extended period of time may help achieve a deeper understanding of their experiences. 


\section{References}

Ashmore, R. D., Deaux, K., \& McLaughlin-Volpe, T. (2004). An organizing framework for collective identity: articulation and significance of multidimensionality. Psychological Bulletin, 130(1), 80.

Attewell, P. (1990). What is skill? Work and occupations, 17(4), 422-448.

Ballantyne, D. (2004). Dialogue and its role in the development of relationship specific knowledge. Journal of Business \& Industrial Marketing, 19(2), 114-123.

Belk, R. W. (1975). Situational variables and consumer behavior. Journal of Consumer Research, 2(3), 157-164.

Billett, S. (2001). Knowing in practice: Re-conceptualising vocational expertise. Learning and Instruction, 11(6), 431-452.

Blackler, F. (1993). Knowledge and the theory of organizations: Organizations as activity systems and the reframing of management. Journal of Management Studies, 30(6), 863884.

Boyatzis, R. E. (2008). Competencies in the 21st century. Journal of Management Development, 27(1), 5-12.

Brewer, M. B., \& Gardner, W. (1996). Who is this "We"? Levels of collective identity and self representations. Journal of Personality and Social Psychology, 71(1), 83.

Dall'Alba, G., \& Sandberg, J. (1996). Educating for competence in professional practice. Instructional science, 24(6), 411-437.

Dekas, K. H., Bauer, T. N., Welle, B., Kurkoski, J., \& Sullivan, S. (2013). Organizational citizenship behavior, version 2.0: A review and qualitative investigation of OCBs for knowledge workers at Google and beyond. The Academy of Management Perspectives, 27(3), 219-237.

Dennis, C., King, T., Fiore, A. M., \& Kim, J. (2007). An integrative framework capturing experiential and utilitarian shopping experience. International Journal of Retail \& Distribution Management, 35(6), 421-442.

Felin, T., Foss, N. J., \& Ployhart, R. E. (2015). The Microfoundations Movement in Strategy and Organization Theory. The Academy of Management Annals, 9(1), 575-632.

FitzPatrick, M., Varey, R. J., Grönroos, C., \& Davey, J. (2015). Relationality in the service logic of value creation. Journal of services marketing, 29(6/7), 463-471.

Grönroos, C. (2008). Service logic revisited: who creates value? And who co-creates? European Business Review, 20(4), 298-314.

Grönroos, C. (2011). A service perspective on business relationships: The value creation, interaction and marketing interface. Industrial Marketing Management, 40(2), 240-247.

Grönroos, C., \& Ravald, A. (2011). Service as business logic: implications for value creation and marketing. Journal of Service Management, 22(1), 5-22.

Grönroos, C., \& Voima, P. (2013). Critical service logic: making sense of value creation and cocreation. Journal of the Academy of Marketing Science, 41(2), 133-150.

Gummesson, E. (2011). 2B or not 2B: That is the question. Industrial Marketing Management, 40(2), 190-192.

Haas, A., Snehota, I., \& Corsaro, D. (2012). Creating value in business relationships: The role of sales. Industrial Marketing Management, 41(1), 94-105.

Hadjikhani, A., \& LaPlaca, P. (2013). Development of B2B marketing theory. Industrial Marketing Management, 42(3), 294-305. 
Helkkula, A., Kelleher, C., \& Pihlström, M. (2012). Characterizing value as an experience: implications for service researchers and managers. Journal of Service Research, 15(1), 59-75.

IMP Group. (1982). International marketing and purchasing of industrial goods: An interaction approach (H. Håkansson Ed.): Wiley Chichester.

Jaakkola, E., \& Hakanen, T. (2013). Value co-creation in solution networks. Industrial Marketing Management, 42(1), 47-58.

Katz, D. (1964). The motivational basis of organizational behavior. Behavioral science, 9(2), 131-146.

Katz, D., \& Kahn, R. L. (1978). The social psychology of organizations (2 ed.). New York: Wiley.

Kohli, A. K. (2011). Looking through the lens of B2B and beyond... Industrial Marketing Management, 40(2), 193-194.

Kowalkowski, C. (2010). What does a service-dominant logic really mean for manufacturing firms?. CIRP Journal of Manufacturing Science and Technology, 3(4), 285-292.

Kvale, S. (1994). Ten standard objections to qualitative research interviews. Journal of phenomenological psychology, 25(2), 147-173.

Kvale, S. (1995). The social construction of validity. Qualitative inquiry, 1(1), 19-40.

Lather, P. (1993). Fertile obsession: Validity after poststructuralism. The sociological quarterly, 34(4), 673-693.

Le Deist, F. D., \& Winterton, J. (2005). What Is Competence? Human Resource Development International, 8(1), 27-46.

Lusch, R. F., \& Nambisan, S. (2015). Service Innovation: A Service-Dominant Logic Perspective. Mis Quarterly, 39(1), 155-175.

MacKenzie, S. B., Podsakoff, P. M., \& Fetter, R. (1991). Organizational citizenship behavior and objective productivity as determinants of managerial evaluations of salespersons' performance. Organizational Behavior and Human Decision Processes, 50(1), 123-150.

Madhavaram, S., Granot, E., \& Badrinarayanan, V. (2014). Relationship marketing strategy: an operant resource perspective. Journal of Business \& Industrial Marketing, 29(4), 275-283.

Miles, M . and Huberman, A . (1994). Qualitative Data Analysis: An Expanded Sourcebook, Beverly Hills, CA: Sage Publications.

Nätti, S., Pekkarinen, S., Hartikka, A., \& Holappa, T. (2014). The intermediator role in value cocreation within a triadic business service relationship. Industrial Marketing Management, 43(6), 977-984.

Organ, D. W. (1988). Organizational citizenship behavior: The good soldier syndrome: Lexington Books/DC Heath and Com.

Pate, J., Martin, G., \& Robertson, M. (2003). Accrediting competencies: a case of Scottish vocational qualifications. Journal of European Industrial Training, 27(2/3/4), 169-176.

Patton, M. Q. (1990). Qualitative Evaluation and Research methods, Newbury Park, California, Sage.

Patton, M. Q. (2002). Qualitative research and evaluation methods. Thousand Oaks: CA, Sage.

Podsakoff, N. P., Whiting, S. W., Podsakoff, P. M., \& Blume, B. D. (2009). Individual-and organizational-level consequences of organizational citizenship behaviors: A metaanalysis. Journal of Applied Psychology, 94(1), 122-141.

Pollio, H. R., Henley, T. B., \& Thompson, C. J. (1997). The phenomenology of everyday life: Empirical investigations of human experience: Cambridge University Press. 
Prahalad, C. K., \& Ramaswamy, V. (2004a). Co-creation experiences: The next practice in value creation. Journal of Interactive Marketing, 18(3), 5-14.

Prahalad, C. K., \& Ramaswamy, V. (2004b). Co-creating unique value with customers. Strategy \& Leadership, 32(3), 4-9.

Ranjan, K. R., \& Read, S. (2014). Value co-creation: concept and measurement. Journal of the Academy of Marketing Science, 44(3), 290-315.

Remenyi, D., Williams, B., Money, A. and Swartz, E. (1998). Doing research in business and management, London, Sage Publications.

Rothbard, N. P., Phillips, K. W., \& Dumas, T. L. (2005). Managing multiple roles: Work-family policies and individuals' desires for segmentation. Organization Science, 16(3), 243-258.

Sandberg, J. (2000). Understanding human competence at work: an interpretative approach. Academy of Management Journal, 43(1), 9-25.

Sandberg, J. (2001). Understanding competence at work. Harvard Business Review, 79(3), 24.

Sandberg, J. (2005). How do we justify knowledge produced within interpretive approaches? Organizational Research Methods, 8(1), 41-68.

Sandberg, J., \& Pinnington, A. H. (2009). Professional competence as ways of being: An existential ontological perspective. Journal of Management Studies, 46(7), 1138-1170.

Schutz, A. (1967). The phenomenology of the social world: Northwestern University Press.

Storbacka, K., Brodie, R. J., Böhmann, T., Maglio, P. P., \& Nenonen, S. (2016). Actor engagement as a microfoundation for value co-creation. Journal of Business Research, 69(8), 3008-3017.

Story, V. M., Raddats, C., Burton, J., Zolkiewski, J., \& Baines, T. (2017). Capabilities for advanced services: A multi-actor perspective. Industrial Marketing Management, 60, 5468.

Taylor, S. J., \& Bogdan, R. (1984). Introduction to qualitative research methods: The search for meaning.

Ueda, K., Takenaka, T., Vancza, J., Monstori, L. (2009). Value creation and decision making in sustainable society. Ann. CIRP 58, 1-24.

Van Scotter, J., Motowidlo, S. J., \& Cross, T. C. (2000). Effects of task performance and contextual performance on systemic rewards. Journal of Applied Psychology, 85(4), 526.

Vargo, S. L., \& Lusch, R. F. (2004). Evolving to a New Dominant Logic for Marketing. Journal of Marketing, 68(1), 1-17.

Vargo, S. L., Maglio, P. P., \& Akaka, M. A. (2008). On value and value co-creation: A service systems and service logic perspective. European Management Journal, 26(3), 145-152.

Weinert, F. E. (1999). Concepts of Competence: Definition and Selection of Competencies. Munich: Max Planck Institute for Psychological Research.

Wendt, A. (1994). Collective identity formation and the international state. American political science review, 88(2), 384-396.

Zeithaml, V. A., Berry, L. L., \& Parasuraman, A. (1993). The nature and determinants of customer expectations of service. Journal of the academy of marketing science, 21(1), 112. 


\section{Appendix 1: Participant Roles}

\begin{tabular}{|c|c|c|c|c|}
\hline $\begin{array}{c}\text { Top } \\
\text { Management }\end{array}$ & Head Level & $\begin{array}{c}\text { Functional head } \\
\text { level }\end{array}$ & Manager Level & Operational Level \\
\hline
\end{tabular}

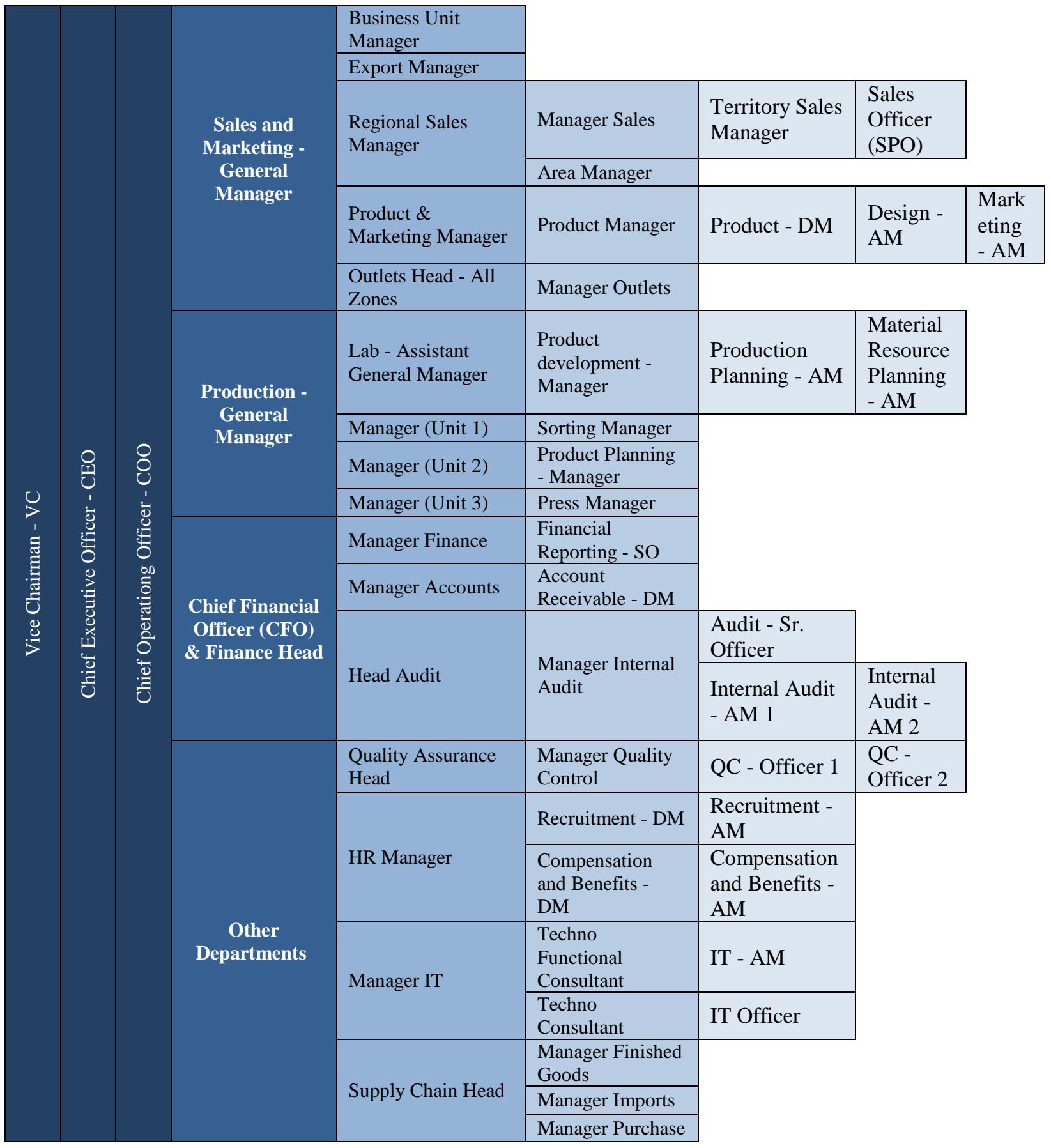

